\title{
Effect of LHRH immunoneutralization on follicular development, the LH surge and luteal function in the stumptailed macaque monkey (Macaca arctoides)
}

\author{
H. M. Fraser, A. S. McNeilly, M. Abbott and R. A. Steiner* \\ M.R.C. Reproductive Biology Unit, Centre for Reproductive Biology, 37 Chalmers Street, Edinburgh \\ EH3 9EW, U.K. and ${ }^{*}$ Department of Obstetrics and Gynecology, Department of Physiology and \\ Biophysics, University of Washington, Seattle, Washington 98195, U.S.A.
}

\begin{abstract}
Summary. A dose of $100 \mu \mathrm{l}$ of a potent ovine LHRH gamma globulin inhibited ovulation in the cyclic rat when administered at $12: 00 \mathrm{~h}$ on the day of pro-oestrus. A dose of $10 \mathrm{ml}$ of the preparation was administered i.v. to female stumptailed macaques to achieve circulating antibody titres 3-4-fold higher than in the rat. In an ovariectomized macaque, this caused a marked fall in serum concentrations of $\mathrm{LH}$ to less than $10 \%$ of pretreatment values and also a significant, though less pronounced, fall in FSH. Six monkeys were treated with the LHRH gamma globulin during the mid-late follicular phase of the cycle. In 2 monkeys in which serum oestradiol concentrations were $<100 \mathrm{pg} / \mathrm{ml}$ at the time of antibody administration, the rising oestradiol levels were abruptly suppressed and the normal mid-cycle LH surge failed to occur. Serum concentrations of $\mathrm{LH}$ and FSH declined to low levels for 8-10 days after which time normal follicular development occurred. In the remaining 4 monkeys in which follicular development was more advanced as indicated by serum oestradiol concentrations of $>100 \mathrm{pg} / \mathrm{ml}$, the antibodies induced either a transient decline or had no effect on the rising serum concentration of oestradiol. An $\mathrm{LH} / \mathrm{FSH}$ surge followed by a rise in serum progesterone occurred in these macaques. When the antibodies were administered to a further 6 macaques, which had also been treated with oestradiol benzoate during the early follicular phase to induce an LH surge, the neutralization of LHRH again failed to block the surge even when the dose of antibody was increased to $20 \mathrm{ml}$.

The results show that $\mathrm{LHRH}$ antibodies were unable to block the $\mathrm{LH}$ surge in the macaque. They contrast with results obtained with LHRH immunoneutralization in the sheep, rat, hamster, mouse and bird and suggest that the ability of oestrogen to induce an LH surge by acting directly on the LHRH-primed anterior pituitary gland is more dominant in the primate.
\end{abstract}

\section{Introduction}

The relative importance of hypothalamic LHRH and the pituitary gonadotroph as sites of the positive feedback action of oestradiol to bring about the mid-cycle gonadotrophin surge in the primate has still to be established. Studies in which LHRH has been neutralized by injection of antibodies a short time before the preovulatory LH surge have prevented the surge and ovulation in the rat (Fraser \& Gunn, 1973; Koch, Chobsieng, Zor, Fridkin \& Lindner, 1973; Arimura, Debeljuk \& Schally, 1974), mouse (Laing, Gosden \& Fraser, 1984), hamster (de la Cruz, Arimura, de la Cruz \& Schally, 1976), sheep (Fraser \& McNeilly, 1982) and chicken (Fraser \& Sharp, 1978). In these species therefore the association between LHRH release and the LH surge is established.

However, in the rhesus monkey withdrawal of LHRH by cutting the pituitary stalk does not 
prevent the oestrogen-induced LH surge (Ferin, Rosenblatt, Carmel, Antunes \& Vande Wiele, 1979). Also, in ovariectomized rhesus monkeys with hypothalamic lesions to prevent endogenous LHRH secretion, restoration of normal serum gonadotrophin concentrations by exogenous LHRH results in the ability of oestrogen to induce an LH surge even when pulses of LHRH are stopped $48 \mathrm{~h}$ before oestrogen administration (Wildt, Hausler, Hutchinson, Marshall \& Knobil, 1981). Furthermore, injection of LHRH antibodies failed to prevent the oestrogen-induced LH surge in ovariectomized rhesus monkeys (McCormack, Plant, Hess \& Knobil, 1977). These results suggested that, in the monkey, the LH surge could be brought about by oestrogen acting directly on the anterior pituitary and that LHRH need only be present to prime the gonadotroph.

In view of our findings, and those of others, that injection of LHRH antibodies could block the LH surge in the chicken, rat, hamster, mouse and sheep (Fraser, McNeilly \& Popkin, 1984, review) we decided to utilize this approach to investigate the role of LHRH in the LH surge in intact stumptailed macaque monkeys which have menstrual cycles similar to those of women.

\section{Materials and Methods}

Preparation of LHRH gamma globulin. A potent LHRH antiserum raised in a ewe (No. 94) by immunization against a human serum albumin (HSA)-LHRH conjugate was used. Specificity was directed towards the C-terminal end of LHRH, but there was no cross-reaction with other peptide hormones (Ellis, Desjardins \& Fraser, 1983). A pool of $1 \cdot 1$ litres antiserum was used to prepare a concentrated gamma globulin fraction with unwanted proteins removed. This was achieved by first centrifuging the antiserum at $10000 \mathrm{~g}$ for $90 \mathrm{~min}$ to remove particulate material, and isolating the gamma globulin fraction by sodium sulphate precipitation (Heide \& Schwick, 1978). After dialysis for 2 days against 5 changes of 3 litres $0.9 \%(\mathrm{w} / \mathrm{v})$ sodium chloride at $4{ }^{\circ} \mathrm{C}$, the preparation was dialysed against sucrose for $3-4 \mathrm{~h}$ to reduce the fluid volume to $25 \%$ of the initial whole serum volume. The preparation was then centrifuged at $2000 \mathrm{~g}$ for $30 \mathrm{~min}$ at $4^{\circ} \mathrm{C}$, the precipitate discarded and the supernatant stored at $-40^{\circ} \mathrm{C}$ until used for passive immunization. LHRH antibody titre, expressed as the highest dilution binding 33\% ${ }^{125}$ I-labelled LHRH, was 1:70 000 for the neat serum and 1:160000 for the gamma globulin preparation. A gamma globulin fraction from serum taken from a ewe immunized against HSA was prepared in a similar manner.

The biological activity of the LHRH gamma globulin was tested in cyclic female SpragueDawley rats housed as described previously (Popkin \& Fraser, 1983) and exhibiting two 4-day oestrous cycles before study. Three groups of 6 rats were lightly anaesthetized with ether at 12:00 h on the day of pro-oestrus and injected into the tail vein with $100 \mu 1$ gamma globulin to HSA (controls) or 50 or $100 \mu \mathrm{l}$ gamma globulin to LHRH. At 17:00 h on the day of pro-oestrus a blood sample was taken from the tail vein under ether anaesthesia; serum was collected and stored at $-20^{\circ} \mathrm{C}$ for radioimmunoassay of $\mathrm{LH}$ and measurement of LHRH antibody titre. The rats were killed at 09:00 $\mathrm{h}$ on the morning of oestrus and the number of ova shed was counted by examining the oviducts under a dissecting microscope (Fraser \& Gunn, 1973).

All control rats ovulated, shedding 12-16 ova. The dose of $50 \mu \mathrm{l} \mathrm{LHRH} \mathrm{gamma} \mathrm{globulin}$ blocked ovulation in 2 of 6 rats while $100 \mu$ was effective in all 6 rats. In control rats at 17:00 h on the day of pro-oestrus, serum concentrations of $\mathrm{LH}$ were elevated at $347 \pm 136 \mathrm{ng} / \mathrm{ml}$ (mean \pm s.e.m.) while in rats injected with $50 \mu \mathrm{l}$ or $100 \mu \mathrm{l}$ LHRH gamma globulin LH levels were $43 \pm 5$ and $40 \pm 4 \mathrm{ng} / \mathrm{ml}$, respectively, significantly lower than in control rats $(P<0.05$, Student's $t$ test $)$. On a volume for weight basis the equivalent dose in the stumptailed macaque would be $4 \mathrm{ml}$, but in view of the protracted events surrounding the LH surge in this species it was decided to administer a dose of $10 \mathrm{ml}$ antibody.

Effect of anti-LHRH in an ovariectomized monkey. In a preliminary study to test the efficacy of the LHRH gamma globulin in the macaque, a monkey ovariectomized 1 year previously and with elevated serum concentrations of LH and FSH was injected wth $10 \mathrm{ml}$ of the LHRH gamma 
globulin. Blood samples were collected from the femoral vein daily for 5 days, before administration of the antibody which was infused into the femoral vein via a 3-way tap over a 2-min period immediately after a blood sample had been collected. Blood samples were collected at regular intervals thereafter for a further 4 weeks.

Effect of anti-LHRH during the normal cycle. Twelve adult female stumptailed macaques with regular ovulatory menstrual cycles, as judged from serum profiles of oestradiol and progesterone and menstrual records over several years before this study, were selected. The animals were housed in two rooms at a temperature of $24-26^{\circ} \mathrm{C}$ open to daylight but also lit artificially between 07:00-19:00 h. They were fed a primate diet (Old World Monkey diet, B.P. Nutrition, Witham, U.K.) daily and given fresh fruit three times per week, with water available ad libitum. Daily blood samples were collected from the femoral vein during the cycle before treatment, the treatment cycle, and for the post-treatment cycle. The animals were used to this procedure, and it caused no apparent stress. An additional blood sample was collected at $8 \mathrm{~h}$ after antibody administration. The length of the follicular phase during the pretreatment cycle ranged from 10 to 15 days followed by a

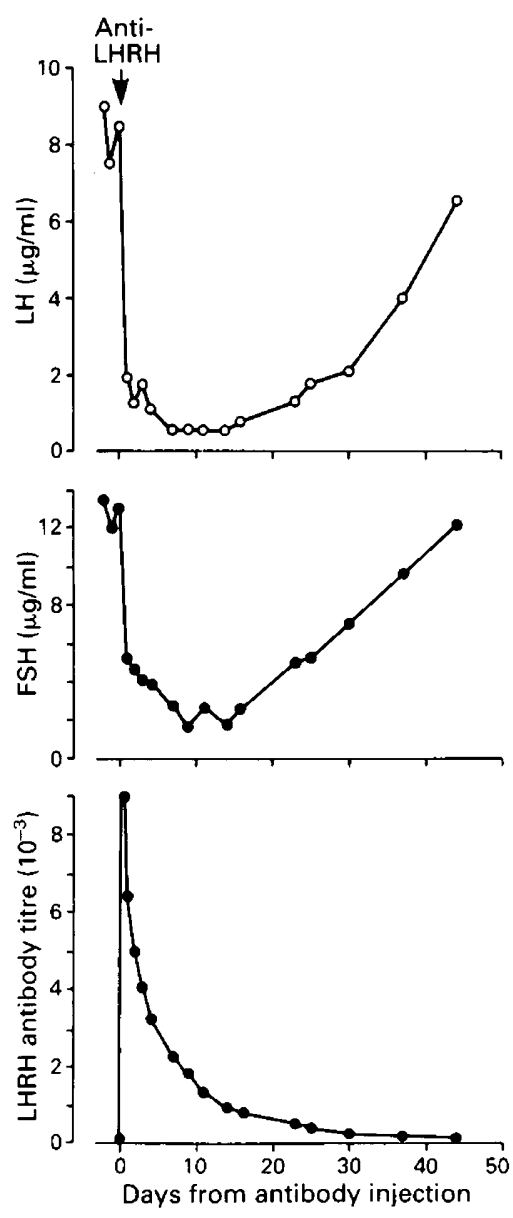

Fig. 1 Effect of an i.v. injection of an LHRH gamma globulin on serum concentrations of (a) LH and (b) FSH in an ovariectomized stumptailed monkey: (c) shows titre of LHRH antibody obtained in the serum. 

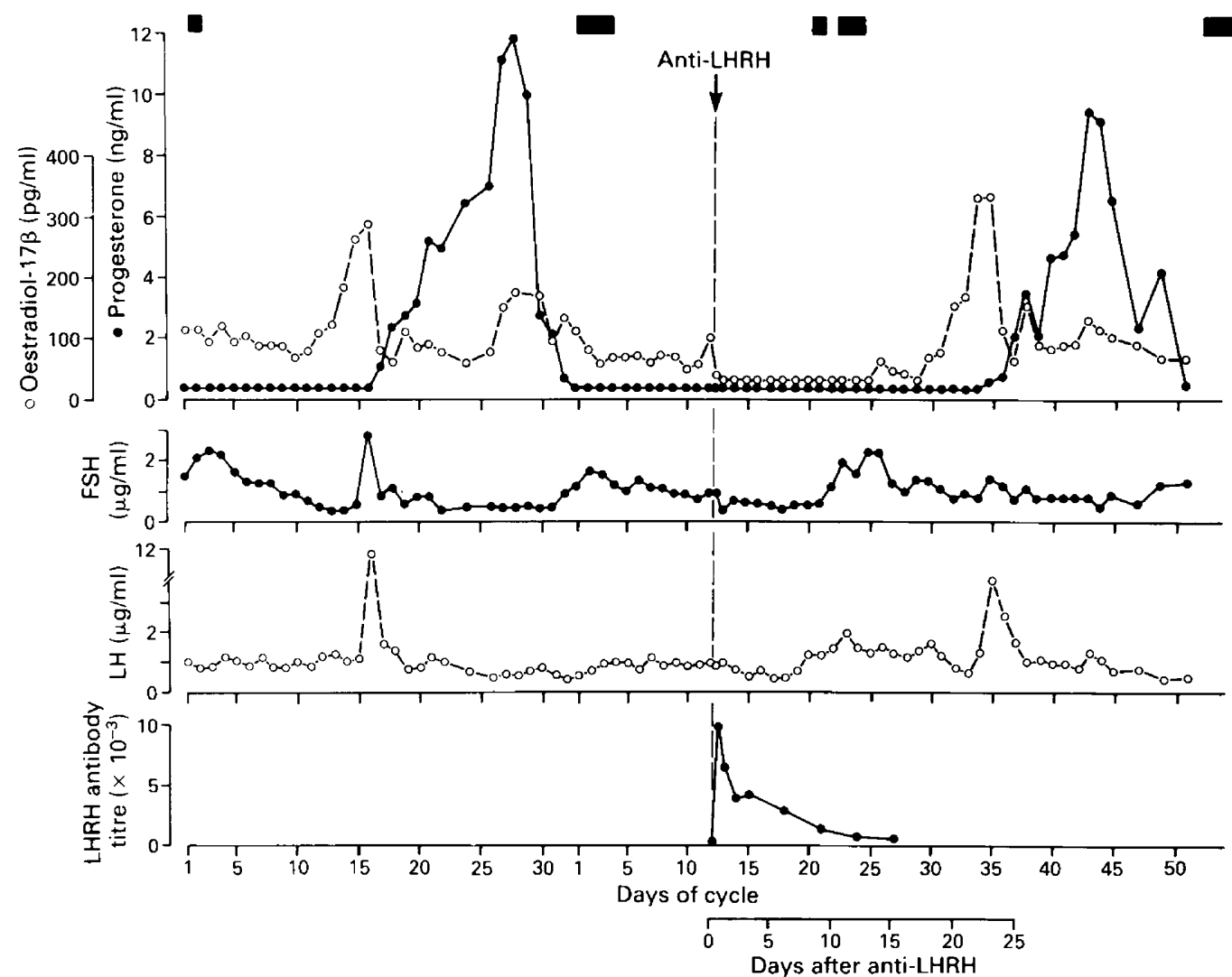

Fig. 2. Serum concentrations of LH, FSH, oestradiol and progesterone during a pretreatment control cycle and during the following cycle of a monkey (No. 70) after an i.v. injection of LHRH gamma globulin during the mid-follicular phase. Bottom panel shows titre of LHRH antibodies in the circulation. Bars show menstrual bleeding.

luteal phase lasting 14-16 days. On Day 10 of the cycle as judged from the first day of menstruation, 3 animals were infused with $10 \mathrm{ml}$ HSA gamma globulin and 9 were infused with LHRH gamma globulin. For purposes of expressing results, Day 1 of the cycle was calculated from the first day of the fall of luteal progesterone to $0.3 \mathrm{ng} / \mathrm{ml}$. In some animals, this preceded detection of menstruation by $2-3$ days.

Effect of LHRH on the oestrogen-induced LH surge. Six monkeys with regular menstrual cycles were given an i.m. injection of $50 \mu \mathrm{g}$ oestradiol benzoate $/ \mathrm{kg}$ (Intervet, Organon Laboratories Ltd, Morden, Surrey) in arachis oil on Days 1-5 of a control cycle, and all exhibited an LH surge beginning 36-48 h later. After 2 or 3 control cycles the same monkeys were again treated with $50 \mu \mathrm{g}$ oestradiol benzoate $/ \mathrm{kg}$ at the same stage of the cycle, but this time were also given an infusion of LHRH gamma globulin $24 \mathrm{~h}$ later $(\mathrm{N}=2)$ or at the same time as oestrogen administration $(\mathrm{N}=4)$. Four of the monkeys received $10 \mathrm{ml}$ LHRH gamma globulin, while 2 of the latter group received $20 \mathrm{ml}$. Blood samples were collected at $0,12,24,36,48,60,72,84,96$ and $108 \mathrm{~h}$ after oestrogen injection.

Radioimmunoassays. Oestradiol and LH were measured by radioimmunoassays as described by Fraser, Laird \& Blakeley (1980) and progesterone as described by Fraser, Baird, McRae, Nestor \& Vickery (1985). Three heterologous radioimmunoassays for FSH were compared for measurement 
of pools of serum from an intact male, an intact female and an ovariectomized stumptailed macaque. All results were measured against the rhesus monkey pituitary gonadotrophin preparation LER 1909-2. Antibodies M91, M94 and NIAMDKD hFSH 5 were all raised to human FSH in rabbits. Tracers tested were ${ }^{125}$ labelled rat FSH (r FSH-1-5; NIAMDKD), human FSH (CPDS-13; Dr S. S. Lynch) and ovine FSH (oFSH-181; Professor M. Jutisz). Use of antiserum hFSH5 gave a sensitivity of $120 \mathrm{ng} /$ tube and maximal displacement of tracer to only $30 \%$. Best results were obtained using M94 in combination with ovine FSH tracer as described previously for sheep (McNeilly, McNeilly, Walton \& Cunningham, 1976). Sensitivity was less than $40 \mathrm{ng} /$ tube and maximal displacement to less than $5 \%$ tracer with $2500 \mathrm{ng} /$ tube. At an initial dilution of 1:2000, $12-25 \%$ counts were specifically bound. Parallel displacement was achieved with all 3 pools of serum. Samples were assayed at $200 \mu \mathrm{l}$ in duplicate. Inter- and intra-assay coefficients of variation were 8 and $10 \%$ respectively.

$L H$ bioassay. Serum $\mathrm{LH}$ concentrations were measured by a modification of the mouse Leydig cell bioassay (Steiner \& Bremner, 1981), originally described by Van Damme, Robertson \& Diczfalusy (1974) and Dufau, Hodgen, Goodman \& Catt (1977). All plasma samples were assayed in triplicate at volumes of 1 or $20 \mu \mathrm{l}$. The assay sensitivity was $0.15 \mu \mathrm{g} / \mathrm{ml}$. The intra- and interassay coefficients of variation were $7 \cdot 9 \%$ and $12 \cdot 1 \%$ respectively.

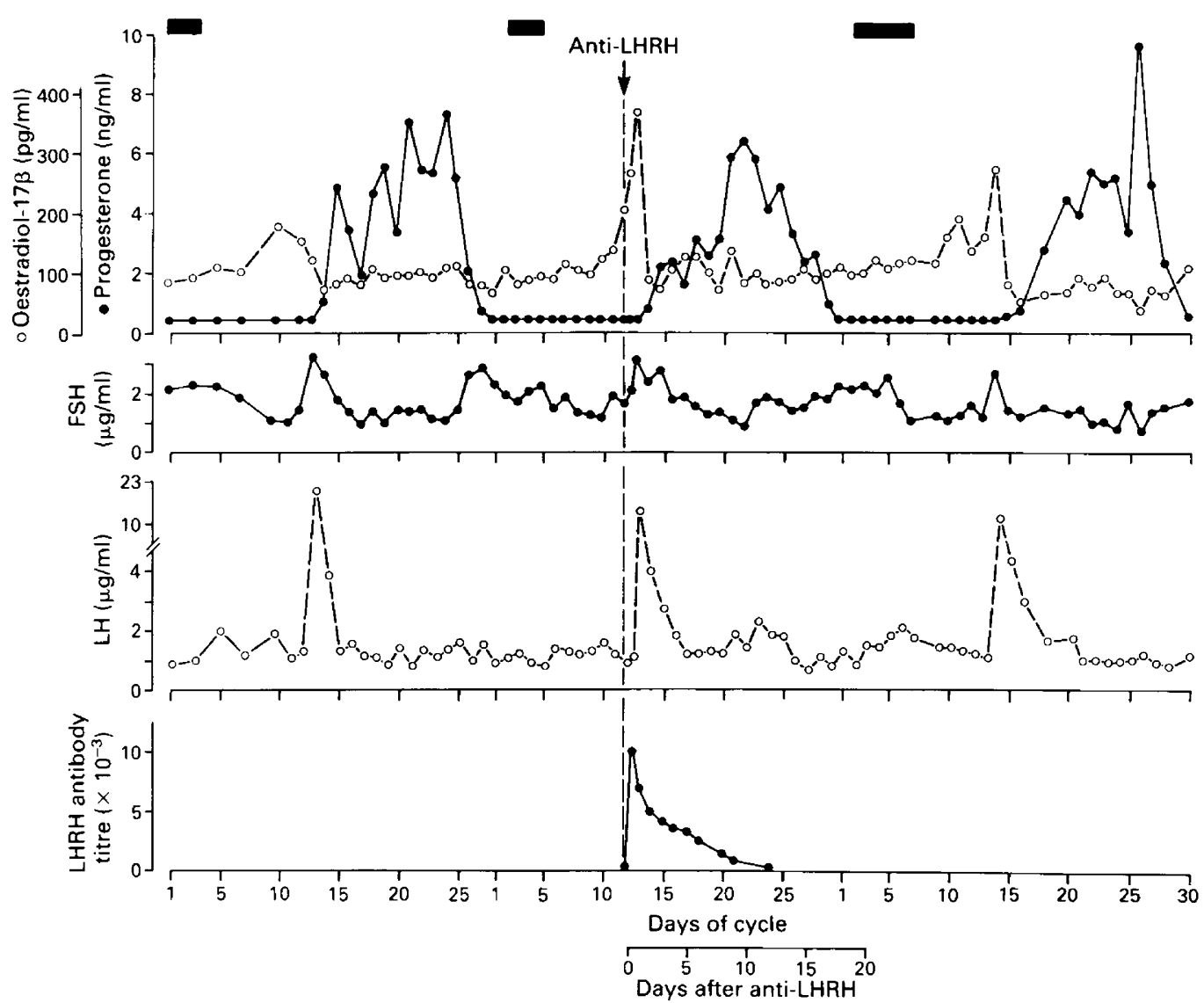

Fig. 3. Serum concentrations of LH, FSH, oestradiol and progesterone during a pretreatment control cycle and during the following cycle of a monkey (No. 58) after an i.v. injection of LHRH gamma globulin during the late follicular phase. Bars show menstrual bleeding. 


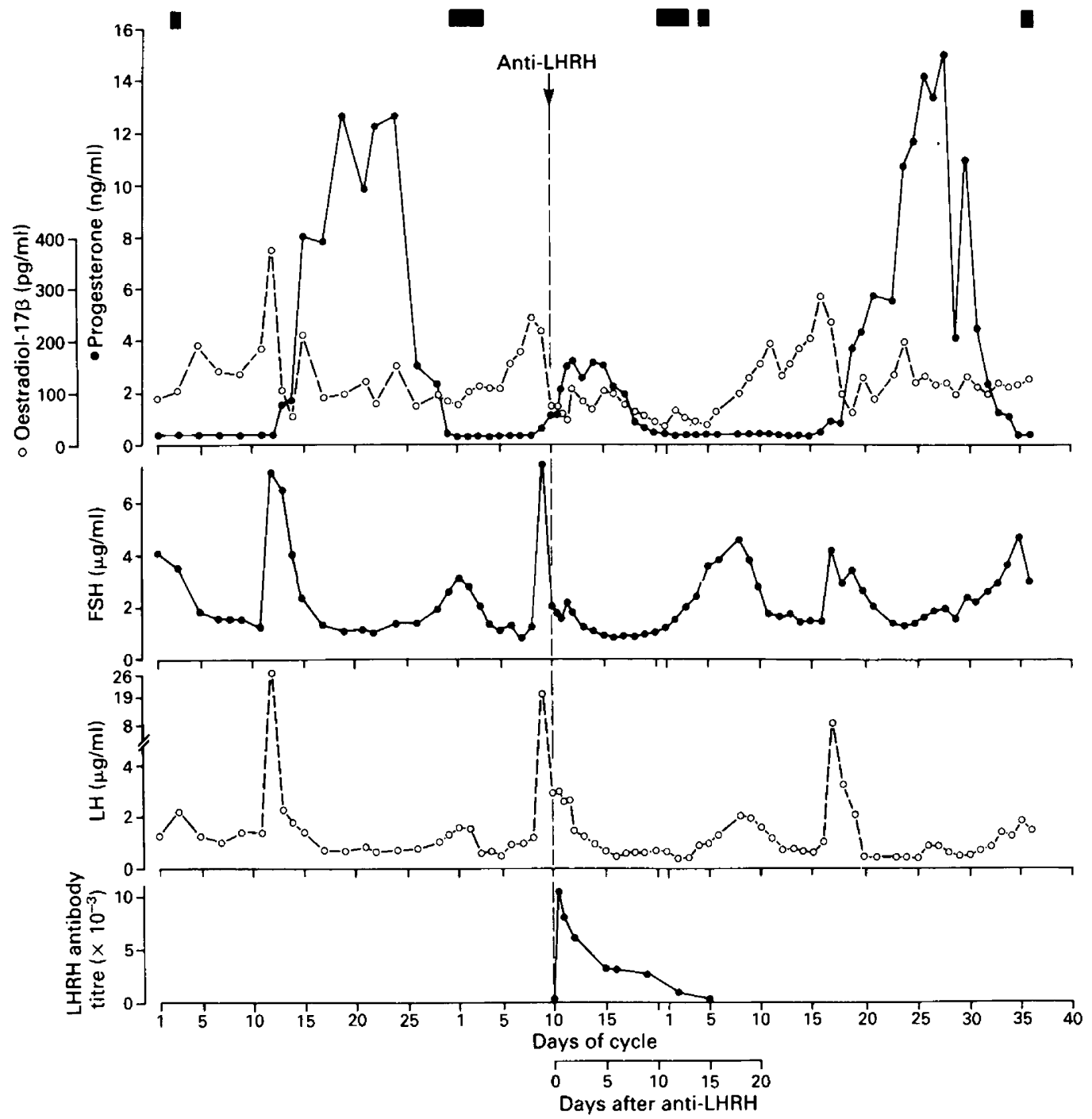

Fig. 4. Serum concentrations of $\mathrm{LH}, \mathrm{FSH}$, oestradiol and progesterone during a pretreatment control cycle and during the following cycle of a monkey (No. 71) after an i.v. injection of LHRH gamma globulin on the day after the preovulatory gonadotrophin surge. Bars show menstrual bleeding.

\section{Results}

\section{Effect of anti-LHRH in an ovariectomized monkey}

At $6 \mathrm{~h}$ after administration of LHRH gamma globulin the circulating titre of LHRH antibody in the ovariectomized monkey, as expressed as the highest dilution binding $33 \%{ }^{125}$ I-labelled LHRH, was 1:9000 falling to $1: 6400$ by $24 \mathrm{~h}$ and, by the 3 rd day, half of the antibodies had disappeared from the blood (Fig. 1). Serum concentrations of LH fell rapidly after antibody administration while FSH values fell more slowly. By 14 days, LHRH antibody titre had fallen to 1:900 and this was followed by a gradual return to elevated serum concentrations of LH and FSH. 
Effects of anti-LHRH during the follicular phase

Administration of HSA gamma globulin to 3 control monkeys was without effect on follicular development and timing of the LH surge. During the pre-treatment cycle, serum concentrations of oestradiol-17 $\beta$ reached a peak of $150-350 \mathrm{pg} / \mathrm{ml}$ in the follicular phase which was followed by an LH surge either on the same day or on the following day (Figs 2, 3,4). Of the 9 monkeys treated with LHRH gamma globulin, 2 were in the mid-follicular phase as judged by serum concentrations of $<100 \mathrm{pg}$ oestradiol $/ \mathrm{ml}, 4$ were in the late follicular phase having oestradiol levels $>100 \mathrm{pg} / \mathrm{ml}$ at the time of antibody administration, while the 3 remaining monkeys had had an $\mathrm{LH}$ surge $24 \mathrm{~h}$ previously.

In the 2 monkeys treated during the mid-follicular phase, the rising levels of oestradiol were rapidly reduced to values around the detection limit of the assay and the expected mid-cycle surge of $\mathrm{LH}$ failed to occur (Fig. 2). In the absence of a progesterone rise, a premature menstruation occurred. Serum concentrations of LH and FSH remained suppressed for 8-10 days after which time they rose to induce follicular development leading to a normal ovulatory cycle. In the 4 monkeys in which follicular development was more advanced, individual serum oestradiol concentrations at time of antibody administration being 115,146, 203 and $232 \mathrm{pg} / \mathrm{ml}$, the LHRH antibodies induced either a transient decline in serum oestradiol concentrations or had no effect on the rising oestradiol (Fig. 3). An LH/FSH surge of normal amplitude and duration occurred in these

(a) Control
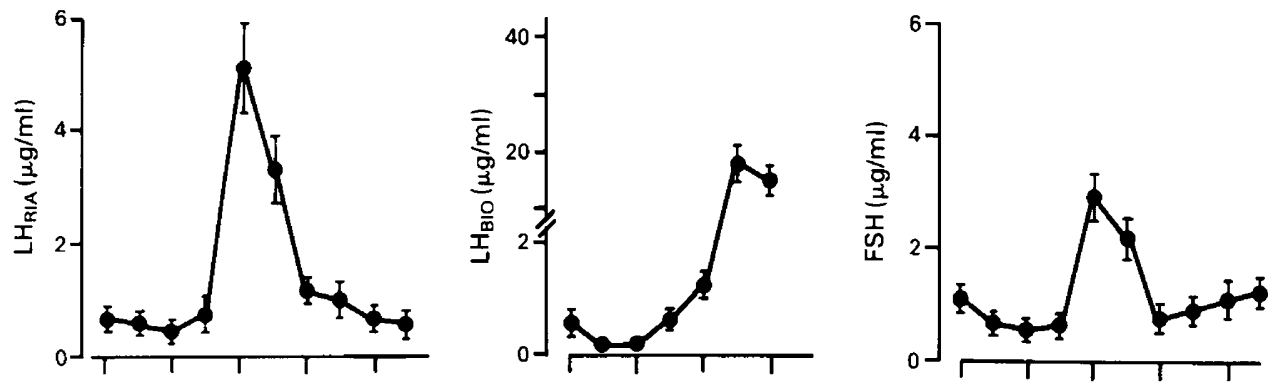

(b) LHRH antibody treated
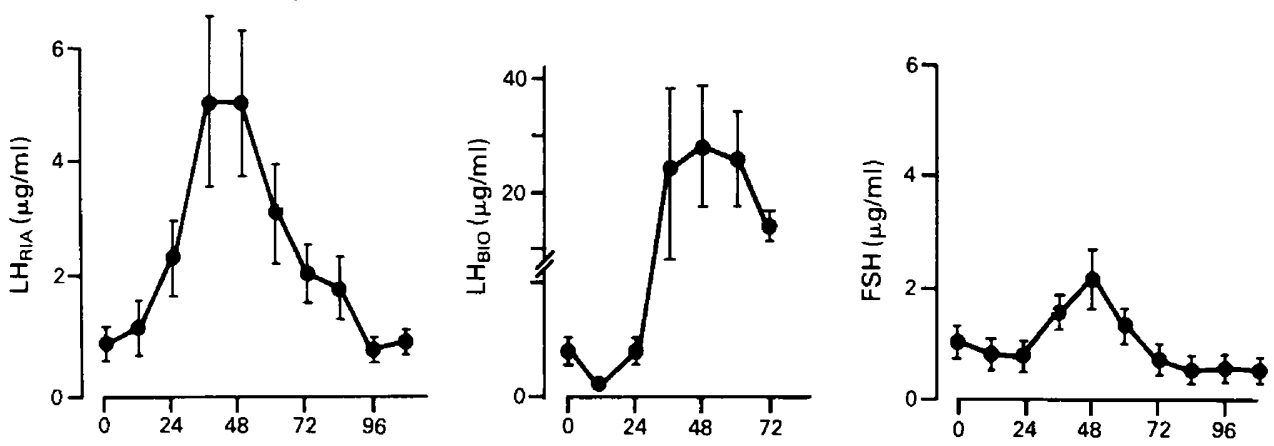

Hours after oestradiol benzoate

Fig. 5. Effect in monkeys of oestradiol benzoate $(50 \mu \mathrm{g} / \mathrm{kg})$ on serum concentrations of immunoreactive and bioactive LH and on FSH on Days 1-5 of the cycle (a) and the effect of an i.v. injection of $10 \mathrm{ml}(\mathrm{N}=2)$ or $20 \mathrm{ml}(\mathrm{N}=2)$ of LHRH gamma globulin given at the same time as oestradiol benzoate to the same animals during a subsequent cycle (b). Values are means \pm s.e.m. 
animals. The duration of the subsequent elevation in serum concentrations of progesterone was normal, although in one animal was clearly of lower magnitude than normal while in the remainder there was a tendency towards low values during the early luteal phase.

\section{Effects of anti-LHRH on luteal function}

Of the 3 monkeys in which the LHRH gamma globulin was injected on the day after the LH peak, one had an apparently normal serum progesterone profile while 2 had only a small, short-lived rise in progesterone lasting 5-8 days and premature menstruation (Fig. 4). After 10 days, serum LH and FSH concentrations began to rise and this was followed by a cycle with normal hormone profiles.

\section{Effect of anti-LHRH on the oestrogen-induced LH surge}

The first 2 monkeys treated with LHRH antibodies $24 \mathrm{~h}$ after administration of oestradiol benzoate both had rises in LH and FSH similar to pretreatment control test (data not shown). The remaining 4 monkeys treated with 10 or $20 \mathrm{ml} \mathrm{LHRH} \mathrm{gamma} \mathrm{globulin} \mathrm{at} \mathrm{the} \mathrm{time} \mathrm{of} \mathrm{oestradiol}$ administration in an effort to achieve longer suppression of LHRH also showed LH and FSH responses of similar amplitude to those of the control test (Fig. 5). In these monkeys levels of immunoreactive LH failed to show any evidence of negative feedback after oestrogen and rose sooner than during the control test. In contrast, LH bioactivity showed a clear fall in $\mathrm{LH} 12 \mathrm{~h}$ after oestradiol benzoate in the test with LHRH-antibody $(P<0.001$, paired $t$ test $)$. However, in agreement with the radioimmunoassay, during the test with LHRH-antibody treatment the LH surge had commenced by $36 \mathrm{~h}$ in all animals compared to $48 \mathrm{~h}$ for the control test.

\section{Comparison of LHRH antibody titres in rats and monkeys}

Serum from rats injected with $100 \mu \mathrm{LHRH}$ gamma globulin at 12:00 $\mathrm{h}$ on the day of prooestrus contained LHRH antibody titres of between 1:2000 and 1:3500 at 17:00 h of pro-oestrus and between 1:1600 and 1:2000 at 09:00 h of oestrus. As expected, sera from all monkeys treated with the antibody had titres 3-4 times these amounts over the equivalent time period (Figs 1-4). In addition the serial dilutions set up to assess antibody titres showed that when the LH surge was occurring in the LHRH antibody-treated monkeys a 1:1000 dilution of the monkey's serum could still bind $>90 \%$ of the LHRH tracer.

\section{Discussion}

The failure of the LHRH gamma globulin to block the preovulatory LH surge when administered during the late follicular phase, or the LH surge induced by oestradiol benzoate, was surprising in view of our previous studies in which we had used similar ovine LHRH antisera to prevent the $\mathrm{LH}$ surge or ovulation in the chicken (Fraser \& Sharp, 1978), mouse (Laing et al., 1984), rat (present study), hamster (H. M. Fraser, unpublished observations) and ewe (Fraser \& McNeilly, 1982; McNeilly, Fraser \& Baird, 1984). One obvious explanation for the results was that the antibodies were ineffective in neutralizing the endogenous LHRH. However, lesser titres of the same gamma globulin fraction were sufficient to block the LH surge and ovulation in the rat. The antibody also markedly suppressed the serum concentrations of LH and FSH in an ovariectomized monkey and blocked the cycle when administered during the mid-follicular phase in 2 monkeys. This antiserum had been previously shown to block LH pulses (Ellis et al., 1983) and LHRH receptor rises in castrated rats (Clayton, Popkin \& Fraser, 1982), suppress serum concentrations of LH and testosterone and LHRH receptor numbers in intact male and female rats (Clayton et al., 1982; 
Fraser, Sharpe, Lincoln \& Harmer, 1982; Popkin \& Fraser, 1983), suppress LHRH receptor numbers in male mice (Naik et al., 1985) and suppress serum testosterone concentrations in male monkeys (Cameron et al., 1985).

There is no doubt that chronic manipulation of LHRH does prevent the oestrogen-induced LH surge in the stumptailed macaque as shown by active immunization against LHRH (Fraser, 1983) or after the opposite approach of chronic LHRH agonist administration (Fraser, 1981). Both these approaches induced chronic changes in stimulation of the gonadotroph. The present results, suggesting that oestrogen can act directly on the LHRH-primed pituitary to induce an LH surge when LHRH was neutralized for a discrete period, would confirm and extend several other observations in the ovariectomized rhesus monkey. For example, McCormack et al. (1977) failed to block the oestrogen-induced LH surge by using a rabbit antiserum to LHRH. Ferin et al. (1979) obtained oestrogen-induced LH surges after pituitary stalk section and placement of a Silastic barrier between the hypothalamus and pituitary. Wildt et al. (1981) were able to elicit an LH surge in ovariectomized rhesus monkeys in which secretion of endogenous LHRH had been blocked by hypothalamic lesions, provided the pituitaries had been primed with exogenous LHRH pulses up to $48 \mathrm{~h}$ before oestrogen administration. Stopping pulses at this time still resulted in an LH surge. These and other (Knobil, 1980) findings have given rise to the concept that, in the primate, oestrogen can act directly on the primed pituitary gland to induce an LH surge, providing it with a 'fail-safe' mechanism not found in other species.

However, these findings contradict those of Norman, Gliessman, Lindstrom, Hill \& Spies (1982) who found that ovulatory cycles could not be restored by LHRH pulses in monkeys with hypothalamic lesions and with a Teflon barrier placed between the hypothalamus and pituitary. The conclusion that hypothalamic LHRH is necessary during the LH surge is supported by the prevention of the surge in ovariectomized rhesus monkeys by an LHRH antagonist (Asch et al., 1983).

The ability of the antibodies in the present study to block follicular development in the mid-, but not the late, follicular phase may be due to increased sensitivity and prolonged responsiveness of the mature follicle to the gonadotrophin stimulation before LHRH antibody administration or to low levels of gonadotrophins produced after the antibody. While it was not possible to measure discrete changes in gonadotrophins in the macaques, studies in sheep show that LHRH antibodies cause an immediate cessation of LH pulses, but low levels of LH may be maintained (Fraser \& McNeilly, 1983; McNeilly et al., 1984).

The possibility that the macaque pituitary is more sensitive than that of other species to low levels of LHRH, remaining active despite the administration of large amounts of a potent antiserum, must also be considered. The resulting circulating titre achieved in the monkeys was higher than that which blocked ovulation in the rat and higher than that obtained by us after successful immunoneutralization of LHRH in the ram (Lincoln \& Fraser, 1979) and in the ewe (McNeilly et al., 1984). In addition, in the present study we showed that, during the time of the LH surge, a dilution of 1:1000 of the monkey's serum was still able to bind more than $90 \%$ of the LHRH tracer in vitro. In view of the high binding of LHRH achieved in these monkeys and the effectiveness of the antiserum in other species we consider that further attempts to increase circulating antibodies would be unjustified and impracticable. We are unable to offer an explanation for the apparent early onset of the LH surge in the monkeys given LHRH antibodies at the time of oestradiol benzoate administration.

The fact that 2 of the 3 monkeys injected with antibodies to LHRH on the day after the LH surge had only a small and short-lived rise in serum progesterone would suggest that the primate corpus luteum is gonadotrophin-dependent. This would agree with recent studies showing declining progesterone concentrations in blood after administration of a potent LHRH antagonist in the stumptailed macaque (Fraser et al., 1985). Also, in rhesus monkeys with hypothalamic lesions in which ovulation had been induced with exogenous LHRH and then this stimulation stopped during the luteal phase (Hutchinson \& Zeleznik, 1984), serum concentration of progesterone fell 
prematurely. The fact that serum progesterone concentrations were not markedly altered in macaques receiving the LHRH antibody before the LH surge may be because the rapidly declining antibody concentrations allow low levels of $\mathrm{LH}$ to be released, sufficient to maintain luteal function. This could also explain why luteal function was apparently unaffected by hypophysectomy or by a less potent LHRH antagonist (Asch, Abou-Samra, Braunstein \& Pauerstein, 1982; Balmaceda, Borghi, Coy, Schally \& Asch, 1983).

In conclusion, the results indicate that the primate differs from other species in that oestrogen can induce an LH surge despite immunoneutralization of LHRH. This would agree with studies using several other approaches to investigate the site of action of oestrogen in bringing about the LH surge in the rhesus monkey. However, as equally convincing investigations have yielded opposite results we feel our conclusions must be tempered by considering other possibilities, a difference in sensitivity to small amounts of LHRH remaining after immunoneutralization being the most obvious.

We thank Ms P. Kolb and Mr N. Laird for expert technical help; Mr I. A. Swanson for preparing radiolabelled progesterone; NIAMDK and Professor M. Jutisz, for gifts of radioimmunoassay reagents; and Dr G. Niswender, Dr S. S. Lynch and Dr H. Dobson for gifts of antisera to LH, FSH and oestradiol respectively. R.A.S. is supported in part by USPHS Grant No. HD 12625.

\section{References}

Arimura, A., Debeljuk, L. \& Schally, A.V. (1974) Blockade of the preovulatory surge of $\mathrm{LH}$ and FSH and of ovulation by anti-LH-RH serum in rats. Endocrinology 95, 323-324.

Asch, R.H., Abou-Samra, M., Braunstein, G.D. \& Pauerstein, C.J. (1982) Luteal function in hypophysectomized rhesus monkeys. J. clin. Endocr. Metab. 55, $154-161$.

Asch, R.H., Balmaceda, J.P., Borghi, M.R., Niesvisky, R., Coy, D.J. \& Schally, A.V. (1983) Suppression of the positive feedback of estradiol benzoate on gonadotropin secretion by an inhibitory analog of luteinizing hormone-releasing hormone (LRH) in oophorectomized rhesus monkeys: evidence for a necessary synergism between LRH and estrogens. $J$. clin. Endocr. Metab. 57, 367-372.

Balmaceda, J.P., Borghi, M.R., Coy, D.H., Schally, A.V. \& Asch, R.H. (1983) Suppression of postovulatory gonadotropin levels does not affect corpus luteum function in rhesus monkeys. J. clin. Endocr. Metab. 57, 866-868.

Cameron, J.L., McNeil, T.H., Fraser, H.M., Bremner, W.J., Clifton, D.K. \& Steiner, R.A. (1985) The role of endogenous gonadotropin-releasing hormone in the control of luteinizing hormone and testosterone secretion in the juvenile male monkey, Macaca fasicularis. Biol. Reprod. (in press).

Clayton, R.N., Popkin, R.M. \& Fraser, H.M. (1982) Hypothalamic regulation of pituitary $\mathrm{GnRH}$ receptors: effects of gonadotrophin-releasing hormone immunoneutralization. Endocrinology 110, 1116-1123.

de la Cruz, A., Arimura, A., de la Cruz, K.G. \& Schally, A.V. (1976) Effect of administration of anti-serum to luteinizing hormone-releasing hormone on gonadal function during the estrous cycle in the hamster. Endocrinology 98, 490-497.
Dufau, M.L., Hodgen, G.D., Goodman, A.L. \& Catt, K.J. (1977) Bioassay of circulating luteinizing hormone in the rhesus monkey: comparison with radioimmunoassay during physiological changes. Endocrinology 110, 1557-1565.

Ellis, G.B., Desjardins, C. \& Fraser, H.M. (1983) Control of pulsatile $\mathrm{LH}$ release in male rats. Neuroendocrinology 37, 177-183.

Ferin, M., Rosenblatt, H., Carmel, P.W., Antunes, J.L. \& Vande Wiele, R.L. (1979) Estrogen-induced gonadotropin surges in female rhesus monkeys after pituitary stalk section. Endocrinology 104, 50-52.

Fraser, H.M. (1981) Effect of oestrogen on gonadotrophin release in stumptailed monkeys (Macaca arctoides) treated chronically with an agonist analogue of luteinizing hormone releasing hormone. J. Endocr. 91, 525-530.

Fraser, H.M. (1983) Active immunization of stumptailed macaque monkeys against luteinizing hormone releasing hormone, and its effects on menstrual cycles, ovarian steroids and positive feedback. $J$. Reprod. Immunol. 5, 173-183.

Fraser, H.M. \& Gunn, A. (1973) Effects of antibodies to luteinizing hormone releasing hormone in the male rabbit and on the rat oestrous cycle. Nature, Lond. 244, 160-161.

Fraser, H.M. \& McNeilly, A.S. (1982) Effect of immunoneutralization of LHRH on the estrogeninduced LH and FSH surges in the ewe. Biol. Reprod. 27, 548-555.

Fraser, H.M. \& McNeilly, A.S. (1983) Differential effects of LH-RH immunoneutralization on $\mathrm{LH}$ and FSH secretion in the ewe. J. Reprod. Fert. 69, 569-577.

Fraser, H.M. \& Sharp, P.J. (1978) Prevention of positive feedback in the hen (Gallus domesticus) by antibodies to luteinizing hormone releasing hormone. J. Endocr. 76, 181-182. 
Fraser, H.M., Laird, N.C. \& Blakeley, D.M. (1980) Decreased pituitary responsiveness and inhibition of the luteinizing hormone surge and ovulation in the stumptailed monkey (Macaca arctoides) by chronic treatment with an agonist analog of luteinizing hormone-releasing hormone. Endocrinology 106, 452-457.

Fraser, H.M., Sharpe, R.M., Lincoln, G.A. \& Harmer, A.J. (1982) LHRH antibodies: their use in the study of hypothalamic LHRH and testicular LHRH-like material, and possible contraceptive applications. In Progress Towards a Male Contraceptive, pp. 41-78. Eds S. L. Jeffcoate \& M. Sandler. John Wiley \& Sons, Ltd, Chichester.

Fraser, H.M., McNeilly, A.S. \& Popkin, R.M. (1984) Passive immunization against LHRH: elucidation of the role of LHRH in controlling LH and FSH secretion and LHRH receptors. In Immunological Aspects of Reproduction in Mammals, pp. 399-418. Ed. D. B. Crighton. Butterworths, London.

Fraser, H.M., Baird, D.T., McRae, G.I., Nestor, J.J. \& Vickery, B.H. (1985) Suppression of luteal progesterone secretion in the stumptailed macaque by an antagonist analogue of luteinizing hormone releasing hormone. J. Endocr. 104, R1-R4.

Heide, K. \& Schwick, H.G. (1978) Salt fractionation of immunoglobulins. In Handbook of Experimental Immunology, vol. 1, pp. 7·1-7·11. Ed. D. M. Weir. Blackwell Scientific Publications, Oxford.

Hutchison, J.S. \& Zeleznik, A.J. (1984) The rhesus monkey corpus luteum is dependent on pituitary gonadotropin secretion throughout the luteal phase of the menstrual cycle. Endocrinology 115, 1780-1786.

Knobil, E. (1980) The neuroendocrine control of the menstrual cycle. Recent Prog. Horm. Res. 36, 53-88.

Koch, Y., Chobsieng, P., Zor, U., Fridkin, M. \& Lindner, H.R. (1973) Suppression of gonadotropin secretion and prevention of ovulation in the rat by antiserum to synthetic gonadotropin-releasing hormone. Biochem. Biophys. Res. Commun. 55, 623-629.

Laing, S.C., Gosden, R.G. \& Fraser, H.M. (1984) Cytogenetic analysis of mouse oocytes after experimental induction of follicular overripening. J. Reprod. Fert. 70, 387-393.
Lincoln, G.A. \& Fraser, H.M. (1979) Blockade of episodic secretion of luteinizing hormone in the ram by the administration of antibodies to luteinizing hormone releasing hormone. Biol. Reprod. 21, 1239-1245.

McCormack, J.T., Plant, T.M., Hess, D.L. \& Knobil, E. (1977) The effect of luteinizing hormone releasing hormone (LHRH) antiserum administration on gonadotropin secretion in the rhesus monkey. Endocrinology 100, 663-667.

McNeilly, A.S., Fraser, H.M. \& Baird, D.T. (1984) Effect of immunoneutralization of LH releasing hormone on LH, FSH and ovarian steroid secretion in the preovulatory phase of the oestrous cycle in the ewe. J. Endocr. 101, 213-219.

McNeilly, J.R., McNeilly, A.S., Walton, J.S. \& Cunningham, F.J. (1976) Development and application of a heterologous radioimmunoassay for ovine follicle-stimulating hormone. J. Endocr. 70, 69-79.

Naik, S.I., Young, L.S., Saade, G., Kujore, A., Charlton, H.M. \& Clayton, R.N. (1985) Role of GnRH in the regulation of pituitary GnRH receptors in female mice. J. Reprod. Fert. 74, 605-614.

Norman, R.L., Gliessman, P., Lindstrom, S.A., Hill, J. \& Spies, H.G. (1982) Reinitiation of ovulatory cycles in pituitary stalk-sectioned rhesus monkeys: evidence for a specific hypothalamic message for the preovulatory release of luteinizing hormone. Endocrinology 111, $1874-1882$.

Popkin, R.M. \& Fraser, H.M. (1983) The effects of immunoneutralization of LHRH or LH on pituitary LHRH receptors during the rat oestrous cycle. Molec. cell. Endocr. 33, 305-312.

Steiner, R.A. \& Bremner, W.J. (1981) Endocrine correlates of sexual development in the male monkey, Macaca fascicularis. Endocrinology 109, 914-919.

Van Damme, M.P., Robertson, D.M. \& Diczfalusy, E. (1974) An improved in vitro bioassay method for measuring luteinizing hormone ( $\mathrm{LH})$ activity using mouse Leydig cell preparations. Acta endocr. Copenh. 77, 655-671.

Wildt, L., Hausler, A., Hutchinson, J.S., Marshall, G. \& Knobil, E. (1981) Estradiol as a gonadotropin releasing hormone in the rhesus monkey. Endocrinology 108, 2011-2013.

Received 1 May 1985 